\title{
Foreign Exchange Rate and Economic Growth Nexus: New Evidence from Nigeria (1981 to 2017)
}

\author{
MUSA, Kabiru Saidu \\ Department of Economics, Faculty of Social and Management Sciences, Bauchi State University Gadau, Yuli \\ Campus Bauchi Nigeria, PMB 065 \\ MUHAMMAD Abdurrahman, \\ Department of Economics, Faculty of Social and Management Sciences, Bauchi State University Gadau, Yuli \\ Campus Bauchi Nigeria, PMB 062 \\ Nafisa MOHAMMED \\ Central Bank of Nigeria, Gombe Branch, Gombe State of Nigeria. \\ Samaila ADAMU \\ Department of Economics and Development Studies, Faculty of Social and Management Sciences, Federal \\ University Kashere, Gombe state of Nigeria, PMB 0182
}

\begin{abstract}
The paper estimates the impact of foreign exchange rate on economic growth of Nigeria. The study makes used of Autoregressive Distributed Lag model (ARDL) on time series Data, for the period 1981-2017. The data set on real effective exchange rate, inflation rate, money supply, lending interest rate, real GDP and foreign direct investment, oil revenue and trade openness (\% of GDP) were tested for stationary using ADF and PP tests and established stationarity at I (1) for five variables and I (0) for two variables. The correlation test result shows that the highest correlation is between money supply and oil revenue while the lowest correlation is between inflation rate and foreign direct investment. The ARDL Co-integration test revealed the existence of long-run relationship among the variables. ARDL test results reveal that real effective exchange rate is negatively and significant in explaining economic growth in Nigeria in the long-run. In the short-run, the lag value of real effective exchange rate is insignificant in explaining the changes in the current rate of economic growth. in the same period, the lag value of money supply is negative and significant in explaining GDP. But in the long run it is positive and significant in explaining economic growth in Nigeria. The rate of inflation both in the short run and long run is negatively and significant in explaining GDP. The Error Correction Term value of $20.7 \%$ shows the speed of adjustment toward long-run equilibrium The findings of the study imply that interest rate in Nigeria is inflationary. Meaning that increase in the rate of interest rate will lead to an increase inflation rate. Therefore, the research study concludes that the impact of foreign exchange rate on the economic growth of Nigeria is negative and significant and that the monetary authorities should adopt flexible exchange rate in Nigeria.
\end{abstract}

Keywords: ARDL, foreign exchange rate, Economic growth, monetary authorities.

DOI: $10.7176 / \mathrm{JESD} / 10-18-18$

Publication date:September $30^{\text {th }} 2019$

\subsection{INTRODUCTION}

The principal of comparative advantage encouraged nations to specialize in the production of the products for which they can easily produce at cheaper rate and in abundance so as to exchange it with other products from other countries. This economic principal had encouraged economic liberalization. Economic liberalization allowed countries to seek exchange of resources (goods and services) with one another. Hence, the concept of exchange rate as a factor crept into the analysis of economic growth. Ufoueze et al, (2018).

It did not feature in the first generation neoclassical growth model Solow (1957) and Rostow (1960) as cited in Todaro and Smith (2004) which focused on savings and investment. The fact that they were closed economy models and dicted that there is no role for exchange rate or exchange rate volatility. The exchange rate is perhaps one of the most widely discussed topics in Nigeria today. This is not surprising given its macroeconomic importance especially in highly import dependent economy as the Nigerian one (Olisadebe, 1991). Thus, the use of exchange rate as an incentive to shift resources into export sector become a policy of interest as a way of boosting national income (Oyovwi, 2012) as cited in Ufoueze et al, (2018).

In Nigeria, since independence in 1960, Nigeria has employed diverse exchange rate policies in an attempt to attain a realistic exchange rate that would ensure efficient allocation of foreign exchange and allow for noninflationary growth of the economy (Inam and Umobong, 2015). Specifically, in a bid to achieve macroeconomic stability, Nigeria's monetary authorities have adopted various exchange rate arrangements over the years. Between 1960 to 1986, the fixed exchange rate system was operated. The inability of the system to achieve the major 
objectives of exchange rate policy led to the reversal of the policy in September 1986 with the fluctuation of the Naira. The flexible exchange rate system was introduced between 1986-1993, a temporary halt to deregulation in 1994 with the "guided deregulation" of the foreign exchange Market, through exchange rate liberalization and the institution of a dual exchange rate mechanism (Oladapo and Oloyede, 2014).

The policy thrust of 1995 was retained in 1996 while the dual exchange rate system crisis was retained in 1997 and 1998. However, all official transactions, except those approved by the Head of State were undertaken in the Autonomous Foreign Market (AFEM). Thus, transactions at the pegged official exchange rate were relatively slimmer. Owing to market imperfections and to sustained in the exchange rate of Naira, the AFEM was replaced with an Inter-Bank Foreign Exchange Market (IFEM) in October 1999 after an initial period of co-existence (Oladapo and Oloyede, 2014).

In the IFEM, a two-way quote system expected to prevail while the market as conducted daily in dispensation, oil companies were allowed to keep their foreign exchange in banks of their choice against the Central Bank of Nigeria (CBN). The CBN has continued to fine tune the IFEM to make it more effective and efficient (Oladapo and Oloyede, 2014).

Exchange rate is an important macroeconomic policy instrument. Changes in exchange rates have powerful effects on trade and non-trade of countries concerned through effects of relative prices of goods and services (Bobai, et al, 2013). Exchange rate refers to the rate at which on currency is exchanged for another (Jhingan, 2013). It is the price of a country's currency expressed in terms of another country's currency. According to Ngerebo-a and Ibe, (2013) Exchange rate is the ratio between a unit of one currency and the amount of another currency for which that unit can be exchange at a time. In another words, exchange rate of currency is the link between domestic and foreign prices. Also, exchange rate can either appreciate or depreciate. Appreciation in the exchange rate occurs if less unit of domestic currency exchanges for a unit of foreign currency while depreciation in exchange rate occurs if more unit of domestic currency exchanges for a unit of foreign currency (Obi et al, 2016).

Exchange rate is the price of one currency vis-a'-vis another and is the number of unit of a currency required to buy another currency (Mordi, 2006). To Eze and Okpala, (2014) exchange rate measures the worth of a domestic economy in terms of another, especially in relation to trading partners' economies. On the other hand, economic growth is the increase in the total market value of the goods and services produced by an economy over time. It is conventionally measured as a percentage rate of increase in real gross domestic product or real GDP (Argyrous, 2004) cited in (Inam and Umobong, 2015).

Economic growth is defined and measured as either: an increase in real gross domestic product (GDP) accruing over some time, or an increase in real GDP per capita occurring over time period (McConnell and Brue, 2005 ) as cited in (Inam and Umobong, 2015). With either definition, economic growth is calculated as a percentage rate of growth per quarter (3-month period) or per year (Inam and Umobong, 2015). The second definition takes into consideration the size of the population. Real GDP per capita (or per capita output) is found by dividing real GDP by the size of the population. (McConnell and Brue, 2005) as cited in (Inam and Umobong, 2015).

The need for foreign exchange rate arises only within the framework of countries engaged in international trade, in contrast to a closed economy, whose scope does not transcend its intra-country trade transactions. This therefore makes this economic issue pertinent in a bid to ensuring a guaranteed growth for the country, owing the fact that majority of the country's raw materials for manufacturing purpose are imported coupled with the fact that Nigeria is one of the major exporters of crude oil and its produces. (Oladapo and Oloyede, 2014).

\subsection{Statement of the problem}

The exchange rate of the Naira was relatively stable between 1973 and 1979, during the oil boom (regulatory era). This was also the situation prior to 1970, when agricultural products accounted for more than $70 \%$ of the nation's gross domestic products (GDP) (Ewa, 2011). However, as a result of the development in the petroleum oil sector, in 1970's the share of agriculture in total exports declined significantly, while that of oil increased. However, from 1981, the world oil market started to deteriorate and its economic crises emerged in Nigeria because of the country's dependence on oil sales for her export earnings. Since the Nigerian economy has remained importdependence on oil-supported, the fluctuation of oil prices would have effect on Nigeria's oil revenue (i.e. major sources of income) Ufoueze et al, (2018). Thus this study is faced with the determining whether the exchange rate has any bearing on Nigerians economic growth and other macroeconomic policy variables.

\subsection{Objectives of the study}

The main objective of this research paper is to investigate the impact of foreign exchange rate on economic growth of Nigeria. The specific objectives include:

1. To determine the impact of exchange rate on real economic growth (RGDP)

2. To determine the impact of inflation rate on real economic growth (RGDP)

3. To determine the impact of interest rate on real economic growth (RGDP)

4. To determine the impact of oil revenue on real economic growth (RGDP) 
5. To determine the impact of foreign direct investment on the real economic growth (RGDP

\subsection{Hypotheses of the study}

$\mathrm{H}_{0}$ : foreign exchange rate does not have significant impact on economic growth of Nigeria.

$\mathrm{H}_{\mathrm{a}}$ : foreign exchange rate has significant impact on economic growth of Nigeria.

It is the aim of this paper to investigate using ARDL model the impact of foreign exchange rate on economic growth of Nigeria for the sample period of 1981 to 2017. The paper is organized into five sections, including this introductory section. The second section is a review of relevant theoretical and empirical literatures. The third section is the model and data. The fourth section focus on results and discussion. Finally, is the conclusion.

\subsection{Literature review}

There is no agreement on choosing the most suitable exchange rate to maintain macroeconomic stability. The choice of an appropriate exchange rate system must depend on the particular features of each country. Free floating exchange rate regimes adopted by developed countries might not suit developing countries whose insurance markets are not so well developed and whose economy is not stable enough to absorb the risks from exchange rate volatility. Therefore, in theory, if the right regime is adopted, it could facilitate better business climate and potentially enhance economic growth in the long-run. Economic theory does not clearly articulate how exchange rate regimes can affect economic growth, and there are a limited number of studies which investigate this relationship (Jakob, 2016).

\subsection{Theoretical framework}

Prior to the monetary approach emphasis of the 1970s, it was common to emphasis international trade flows as primary determinants of exchange rates. Some of the recent advances in exchange rate theory are as follows:

The portfolio Balance theory: this theory developed by Branson et al, (1975) assumes that residents distribute their wealth among three forms of assets- monetary base, domestic bonds, and foreign bonds. Exchange rate is in equilibrium when the holding of these assets are in their desired proportion. In portfolio analysis, the current account balance becomes the reflection of the government budgetary imbalance when the private sector is satisfied with the holding of financial assets. The inability of government to sell bonds to foreigners without an excessive fall in their prices reflected in the overall balance of payment deficit Eze and Okpala, (2014).

The Purchasing Power Parity theory: according to Jhingan (2013), this theory states that equilibrium exchange rate between two inconvertible paper currencies is determined by the equality of the relative change in the price levels in the two countries. International competitiveness is measured in a common currency. The purchasing power parity this theory, countries with higher domestic inflation than their competitors would face their appreciating exchange rate.

The Balance of Payment theory: as demonstrated by Jhingan (2013), under a free exchange rate regime, a country's exchange rate depends upon its Balance of payments. A favorable balance of payments raises the exchange rates, with an unfavorable balance of payments reduces the exchange rate. By implication, exchange rate is determined by the demand and supply of foreign exchange. According to this theory, adjustments in the balance of payments can be made through devaluations and revaluations of some currencies in the case of deficits and surpluses respectively in the balance of payments.

\subsection{Empirical literature}

Most studies in Nigeria focus on the impact of exchange rate volatility on trade balance and investment with little attention to other macroeconomic variables shocks. The review on the impact of foreign exchange rate on economic growth are divided into those with positive relationship and those with negative relationship.

\section{Positive relationship}

Adeniran et al, (2014) examined the impact of exchange rate fluctuation on economic growth from 1986 to 2015 using secondary date on gross domestic product, exchange rate, interest rate and inflation rate in Nigeria. The data were analyze using correlation and Ordinary Least Squares (OLS). The result revealed that exchange rate has positive and insignificant impact while interest rate and inflation rate shows negative and insignificant impact on economic growth in Nigeria. The study recommends that government should encourage the export promotion strategies in order to maintain a surplus balance of trade and also conducive environment, adequate security, effective fiscal and monetary, as well as infrastructural facilities should be provided so that foreign investor will be attracted to invest in Nigeria.

Eze and Okpala (2014) tested the impact of the two basic exchange are policies, namely, the fixed and flexible regimes, using the Chow test procedures to determine the structural stability of the relationship between exchange rate and output of goods and services during the two regimes. The time series date on government expenditure, exchange rate, money supply for the period of 1970-2011. Using ADF test for unit roots and co-integration tests, all the variables were integrated of I (0) and co-integrated. The long-run estimates revealed that, apart from 
government expenditure, both exchange rate and money supply are highly significant in the determination of Nigeria's economic growth performance. The Chow test showed that the relationship between exchange rate and economic growth performance in Nigeria have not undergone any significant structural changes. The study conclude that Nigeria can substantially improve on its economic growth performance through improvement in the overall management of its exchange rate policy.

Oiro (2015) investigated how real exchange rate volatility affected exports of key Kenyan commodities namely; tea, coffee and horticulture for the period of 2005-2012 to the European Union and United Kingdom using GARCH model. The ADF test results shows that coffee is stationary at level value while tea and horticulture are significant at first difference. The ADRL Bound test established a presence of long-run relationship between exchange rate volatility and key commodity exports. The result revealed that foreign income played an important role in explaining tea and coffee exports to the UK and EU. He recommended that greater value addition be done to tea and coffee to ensure that their demand increases with increase in foreign income.

Inam and Umobong (2015) analyses the relationship between exchange rate movements and economic growth in Nigeria using annual data spanning 1970 to 2011. The study employed augmented Dickey Fuller test (ADF) for stationarity of the series, Ordinary Least Squares (OLS) and Granger Causality test, the result of ADF revealed that the variables are integrated of order I (0) and I (1), while the OLS shows the existence of a positive and insignificant relationship between exchange rate and economic growth in Nigeria. The causality test indicates that there is no causality exchange rate and economic growth in Nigeria. The study recommends that government should adopt appropriate monetary and fiscal policies that will not only ensure a realistic and stable exchange rate but will also serve to faster economic growth in Nigeria.

Aslam (2016) tested the impact of exchange rate on the economic growth in Sri lank. The study makes use of the annual time series data from 1970 to 2015 on the gross domestic product, exchange rate, inflation rate and interest rate were considered. Using augmented Dickey Fuller test (ADF) for stationarity of the variables and Ordinary Least Squares (OLS) method, the result shows that GDP is significant at I (0) while other variables are significant at I (1). The OLS test result also shows that exchange rate positively and significantly influenced economic growth whereas inflation and interest rates shows negative and significant impact on economic growth in Sri Lanka.

Jakob (2016) examined the impact of exchange rate regimes on economic growth for the year 2012. Secondary data on gross domestic formation (\%GDP), government expenditure, and index of per capita per person for 74 countries for 2012. The data were analyzed using Ordinary Least Squares (OLS) method and Correlation analysis. The results found that there is a positive and significant correlation between pegged exchange rate, index of government spending and growth in GDP. The index of human capital and inflation have negative and significant correlation with GDP.

Razzaque et al. (2017) study the effects of exchange rate movements on economic growth of Bangladesh for the period 1980-2012 using Error correction model. ADF result shows that all the variables are stationary at first difference. The result of ECM suggest that in the long-run, a 10\% depreciation of the real exchange rate is associated with, on average, a 3.2\% rise in aggregate output. A contractionary effect is observed in the short-run so that the same magnitude of real depreciation would result in a to the European Union using GARCH model bout a half per cent decline in GDP. While the long-run expansionary effect of real depreciations may be appealing for considering exchange rate policy as a development strategy, the like hood of rising inflationary pressures need to be kept in mind while pursuing this policy option.

Koirala (2018) assess the impact of real effective exchange rate (RRR) on economic growth of Nepal. The study uses time series data on GDP, Money supply, level of trade openness, real gross fixed capital formation and real effective exchange rate for the period of 1975-2015. ADF test for stationarity shows that all the variables are non-stationary at first difference. The result of Engle Granger test for co-integration concludes that the variables are co-integrated. The result of ECM revealed that real effective exchange rate has a positive impact on the real GDP of Nepal. The researcher recommended that broad money supply continues be relevant monetary policy for Nepal. Moreover, Nepal must use the real exchange rate as one of the macroeconomic policies.

\section{Negative relationship}

Obi et al. (2016) examine the relationship between exchange rate regimes and output growth in Nigeria in different periods from 1970 to 2014. The study employs the Generalized Method of Moment (GMM) to estimate economic growth equation as a result of indigeneity problem. The finding of study strongly suggest that exchange rate regimes indeed matter in term of the of real economic performance of Nigeria. The overall findings suggested that fixed exchange rates constrain the performance of the Nigerian economy as real exchange rate depicts inverse relationship with the economic growth during the whole period of and period of fixed exchange rate regime. Therefore, the study recommended that sustainability of the regime of exchange rate liberalization that has been in operation from 1986.

Perpetua (2014) examine the impact of exchange rate variation and inflation on the economic growth of Nigeria. The data on official exchange rate, inflation rate, import, export and GDP for the period of 1980-2010 
were considered. Using OLS the result revealed that import and export are positively and statistically insignificant in explaining exchange rate whereas inflation rate is positively and significantly related to exchange rate. GDP shows negative relationship. The study recommended that macroeconomic policies aimed at enhancing sustainable economic development should not over concentrate at fighting inflation but should on other area of economic development such as input productivity and human capital development.

Ufoeze et al. (2018) study the effect of exchange rate fluctuations on Nigerian economy. Using a time series data covering the period of 1970 to 2012, OLS technique was employed to analyzed the secondary data on GDP, exchange rate, money supply, inflation arte and oil revenue. The result revealed that floating exchange rate era is more effective in explaining economic trends in Nigeria. And Exchange rate and inflation rate have negative and significant effects on economic growth while money supply and oil revenue have positive and significant impact in explaining economic growth in Nigeria. The study concludes that exchange rate movement is good indicator for monitoring Nigerian economic growth and the floating exchange rate has outperformed the fixed exchange rate in terms of contribution to inflation, money supply and oil revenue to economic growth.

Barguellil et al. (2018) examines the impact of exchange rate volatility on economic growth. Using a sample of 45 developing and emerging countries over the period of 1985 to 2015 . Using the difference and system generalized methods of moments, the results suggest that the generalized autoregressive conditional heteroscedasticity-based measure of nominal and real exchange rate volatility has negative impact on economic growth. Also, the effect of exchange rate volatility depends on the exchange rate regimes and financial openness, that is, volatility is more harmful when countries adopt flexible exchange rate regimes and financial openness.

Evidence from around the work and evidence from Nigeria shows that the relationship between the foreign exchange rate and economic growth is documented and got mixed [ positive and negative result] results which are confirmed in the literatures of this study. In this circumstance, a research gap about the relationship between foreign exchange rate and economic growth in Nigerian context is formulated. Therefore, this study fills the gap using ARDL approach on annual time series data of Nigeria from 1981-2018.

\subsection{MODEL AND DATA}

Data used in this research, were sourced from development indicators (WDI) and CBN Statistical Bulletin for the entire periods of study 1981 - 2017. Data on Real GDP, Consumer price index, official exchange rate, lending interest rate and Foreign direct investment were source from development indicators (WDI) whereas Oil revenue and Broad money supply were obtained from CBN statistical Bulletin. The choice of the study period was based on the availability of data on most of the variables. Consumer price index (CPI) in this study is a proxy for inflation for Nigeria. While Broad Money is a proxy for money supply in the economy, and Real GDP is a measure of economic growth whereas the lending interest rate is the interest rate of the country. Exchange rate is a measure of official exchange rate, oil revenue is the measure of federally collected oil revenue and foreign direct investment. All data are in logarithm form for uniformity of interpretations and easy measurements. The study makes use of the Autoregressive Distributed Lag Model (ARDL) approach for co-integration developed by Pesaran et al. (2001). ARDL could be applied irrespective of the order of integration of the variables, i.e., whether the variables are I (0), I (1) or mixed. Again, with ARDL, both the long-run and short-run estimates could be obtained simultaneously. Also, it is suitable technique for both large and small sample size between 30 to 80 observations. To test for cointegration relationship among the variables of interest, the null hypothesis of no co-integration $\left(\mathrm{H}_{0}: \alpha_{1}=\alpha_{2}=\alpha_{3}\right.$ $\left.=\alpha_{4}=\alpha_{5}=\alpha_{6}=\alpha_{7}=0\right)$ will be tested against the alternative hypothesis $\left(H_{a}: \alpha_{1} \neq \alpha_{2} \neq \alpha_{3} \neq \alpha_{4} \neq \alpha_{5} \neq \alpha_{6} \neq \alpha_{7} \neq 0\right)$ which indicates the existence of co-integration relationship. The co-integration test is based on F-test/Wald test and is conducted using ordinary least squares. The inference here is, if the computed F-statistic is greater than the upper bound critical values, there is said to be co-integration. If the computed F-statistic is less than the lower bound critical value, there is no co-integration. However, if the value of the computed F-statistic lies between the upper and the lower critical values, then the inference is said to be inconclusive. This study will best be understood using the Solow growth model. The study utilized the simple A-K growth model Equation to derive the foreign exchange rate function.

$Y_{t}=A_{t} K_{t}^{\alpha} L_{t}^{1-\alpha}$

$\mathrm{Y}_{\mathrm{t}}=$ Output Level

$\mathrm{A}_{\mathrm{t}}=$ Constant representing efficiency parameter

$\mathrm{K}_{\mathrm{t}}=$ Capital

$\mathrm{L}_{\mathrm{t}}=$ Labour

$\alpha$ and 1- $\alpha$ are the elasticity of outputs in respect to inputs. Basically, exchange rate takes the form of affecting the quantity and quality of $\mathrm{K}_{\mathrm{t}}$ capital in the model, which is measured and captured by the constant factor $\mathrm{A}_{\mathrm{t}}$.

This study adopted and modify the equation used by Ufoeze et al. (2018). In their model, exchange rate, inflation rate money supply and oil revenue were used as dependent variables and growth rate of GDP was used as dependent variable. As a modification, this study adapted from Ufoeze et al. (2018) and then included openness, foreign direct investment that are capable of influencing foreign exchange rate in Nigeria. This could be stated 
mathematically as follows:

$\mathrm{RGDP}=\mathrm{f}(\mathrm{EXC}, \mathrm{INF}, \mathrm{MS}, \mathrm{OREV}, \mathrm{OPN}, \mathrm{FDI})$

The econometric log form of the model is given as:

$\mathrm{RGDP}_{\mathrm{t}}=\lambda_{0}+\lambda_{1} \operatorname{lnEXCH}_{\mathrm{t}}+\lambda_{2} \operatorname{lnINF}_{\mathrm{t}}+\lambda_{3} \operatorname{lnMS}_{\mathrm{t}}+\lambda_{4} \operatorname{lnMS}_{\mathrm{t}}+\lambda_{5} \operatorname{lnOREV}_{\mathrm{t}}+\lambda_{2} \operatorname{lnOPN}_{\mathrm{t}}+\lambda_{6} \operatorname{lnFDI}_{\mathrm{t}}$

\subsection{Model Specification}

\section{(i) Unit Root Test}

When data exhibit unit root, it means they are non-stationary. When non-stationary series data is regressed on another non-stationary data, it will lead to spurious or non-sense regression.in order to avoid non-sense regression, this paper adopts the Augmented Dickey Fuller Test (ADF) with Philip-Perron (PP) test and Kwiatkowski-PhillipsSchmidt-Shin test (KPS) to serve as the robust check. The unit root model is written as:

No intercept and no trend

$\mathrm{Z}_{\mathrm{t}}=\mathrm{Z}_{\mathrm{t}-1}+u_{\mathrm{t}}$

With Intercept

$\mathrm{Z}_{\mathrm{t}}=\beta_{0}+\mathrm{Z}_{\mathrm{t}-1}+u_{\mathrm{t}}$

With Trend and Intercept

$\mathrm{Z}_{\mathrm{t}}=\beta_{0}+\theta \mathrm{t}+\mathrm{Z}_{\mathrm{t}-1}+u_{\mathrm{t}}$

Where $u_{\mathrm{t}}$ is the residual term and $\mathrm{Z}_{\mathrm{t}}$ is the time series variables.

(ii) utoregressive Distributive Lag Model (ARDL)

The ARDL is used for both testing the long-run relationship and estimating the coefficients of long-run parameters among the variables which are I (1) and I (0). The ARDL model for this paper is presented in equation (5) as follows:

$\Delta \mathrm{RGDP}_{\mathrm{t}}=\gamma_{0}+\sum_{i=1}^{k} \gamma \mathrm{i} \Delta \operatorname{lnRGDPt}-\mathrm{i}+\sum_{i=0}^{k} \gamma \mathrm{i} \Delta \ln \mathrm{lnCHt}-\mathrm{i}+\sum_{i=1}^{k} \gamma \mathrm{i} \Delta \ln \mathrm{INFt}-\mathrm{i}+\sum_{i=0}^{k} \gamma \mathrm{i} \Delta \ln \mathrm{MSt}-\mathrm{i}+$ $\sum_{i=0}^{k} \gamma \mathrm{i} \Delta \ln O P N \mathrm{t}-\mathrm{i}+\sum_{i=0}^{k} \gamma \mathrm{i} \Delta \operatorname{lnOREVt}-\mathrm{i}+\sum_{i=0}^{k} \gamma \mathrm{i} \Delta \ln$ OREVt $-\mathrm{i} \sum_{i=0}^{k} \gamma \mathrm{i} \Delta \ln F D I t-\mathrm{i}+\psi \quad{ }_{1} \ln \operatorname{lnCC}_{\mathrm{t}-1}+$ $\psi_{2} \operatorname{lnINF}_{\mathrm{t}-1}+\psi_{3} \operatorname{lnMS}_{\mathrm{t}-1}+\psi_{4} \operatorname{lnOREV}_{\mathrm{t}-1}+\psi_{5} \operatorname{lnFDI}_{\mathrm{t}-1}+u_{\mathrm{t}}$

Where $\gamma i^{\prime}$ s are the coefficients of short-run and $\psi_{1-} \psi_{6}$ are the long-run coefficients, the rest as defined in the previous Equations.

Once co-integration relationship exists, the long-run model would be estimated as specified:

$\mathrm{RGDP}_{\mathrm{t}}=\delta_{1}+\sum_{i=1}^{q} \phi 1 \mathrm{ilnRGDPt}-\mathrm{i}+\sum_{i=0}^{q} \phi 2 \mathrm{ilnEXCHt}-\mathrm{i}+\sum_{i=1}^{q} \phi 3 \mathrm{ilnINFt}-\mathrm{i}+\sum_{i=0}^{q} \phi 4 \mathrm{ilnMSt}-\mathrm{i}+$ $\sum_{i=0}^{q} \phi 5 \mathrm{ilnOPNt}-\mathrm{i}+\sum_{i=0}^{q} \phi 5 \mathrm{ilnOREVt}-\mathrm{i}+\sum_{i=0}^{q} \phi 6 \mathrm{ilnFDIt}-\mathrm{i}+u_{\mathrm{t}}$

The short-run model of the error correction specification would be estimated to ascertain the short-run dynamic behavior of the variables in the model as follow:

$\Delta \mathrm{RGDP}_{\mathrm{t}}=\beta_{1}++\sum_{i=1}^{m} \varphi 1 \mathrm{i} \Delta \operatorname{lnRGDPt}-\mathrm{i}+\sum_{i=0}^{m} \varphi 2 \mathrm{i} \Delta \ln E X C H \mathrm{t}-\mathrm{i}+\sum_{i=1}^{m} \varphi 3 \mathrm{i} \Delta \ln I N F t-\mathrm{i}+$ $\sum_{i=0}^{m} \varphi 4 \mathrm{i} \Delta \ln M S t-\mathrm{i}+\sum_{i=0}^{m} \varphi 5 \mathrm{i} \Delta \ln 0 P N t-\mathrm{i}+\sum_{i=0}^{m} \varphi 5 \mathrm{i} \Delta \ln 0 R E V t-\mathrm{i}+\sum_{i=0}^{m} \varphi 6 \mathrm{i} \Delta \ln \ln \mathrm{RIt}-\mathrm{i}+\Omega \mathrm{ECT}_{\mathrm{t}-1}+$ $\varepsilon_{\mathrm{t}}$

$\mathrm{ECM}=\operatorname{lnRGDPt}-\varphi 0 \quad-\sum_{i=1}^{m} \delta 1$ ilnRGDPt $-\mathrm{i}-\sum_{i=0}^{m} \Omega 1$ ilnEXCHt $-\mathrm{i} \quad-\sum_{i=0}^{m} \chi 1 \mathrm{ilnINFt}-\mathrm{i}$ $-\sum_{i=0}^{m} \eta 1 \mathrm{ilnMSt}-\mathrm{i}-\sum_{i=1}^{m} \pi 1 \mathrm{ilnOPNt}-\mathrm{i}-\sum_{i=0}^{m} \Psi 1$ ilnOREVt $-\mathrm{i}-\sum_{i=0}^{k} \Phi 1$ ilnFDIt $-\mathrm{i}$

Where ECM is the error correction term $\Omega$ is the coefficient of the error term which measures the speed of adjustment of the variables back to equilibrium in the long-run. It also shows the percentage of deviation from the equilibrium that need to be corrected.

\subsection{Empirical Results}

This section presents the results of the estimation and discusses the findings of the study. The descriptive statistics are presented in Table 1 with the correlation analysis of the variables used in the study. It is observed that from Table that the average values of RGDP is approximately 3.44, REEX is approximately 151.57 , INR is approximately 17.78 , INF is approximately 19.52 . MS is approximately $5.43 \mathrm{E}+12$, OREV is $2.26 \mathrm{E}+12$ and FDI is $2.72 \mathrm{E}+09$. All the variables are positively skewed as indicated by the positive skewness coefficients for all the variables. The study also tested for data normality using Jaque Bera normality test. The data for REEX, INF, MS and FDI are found to be not normally distributed since the $\mathrm{p}$ values for Jarque Bera test were less than 0.05 for all these variables. Using correlation analysis, all the variables are in logarithm form. The highest approximated value of correlation is between MS and $\operatorname{lnOREV}_{\mathrm{t}}$ which is approximately 0.96523 and between RGDP and $\operatorname{lnMS}_{\mathrm{t}}$ which is approximately 0.96152 , followed by the lowest approximated value of correlation is between INF and lnFDI 
which is approximately -0.14019 . and RGDP shows negative correlation with $\operatorname{lnREEX} \mathrm{X}_{\mathrm{t}}, \operatorname{lnINF}_{\mathrm{t}}$. REEX is also negatively correlated with $\operatorname{lnINR}, \operatorname{lnINF}_{t}, \operatorname{lnMS}_{t}$ and $\operatorname{lnOREV} V_{t}$. while INR is positively correlated with $\ln I N F_{t}, \operatorname{lnMS}_{t}$ and $\operatorname{lnOREV}$.

Table 1. Descriptive Statistics of the Variables

\begin{tabular}{|c|c|c|c|c|c|c|c|}
\hline & RGDP & REEX & INR & INF & MS & OREV & FDI \\
\hline Mean & $3.44 \mathrm{E}+13$ & 151.5720 & 17.78058 & 19.51915 & $5.43 \mathrm{E}+12$ & $2.26 \mathrm{E}+12$ & $2.72 \mathrm{E}+09$ \\
\hline Median & $2.42 \mathrm{E}+13$ & 100.4769 & 17.58500 & 12.87658 & $7.00 \mathrm{E}+11$ & $7.24 \mathrm{E}+11$ & $1.59 \mathrm{E}+09$ \\
\hline Maximum & $6.98 \mathrm{E}+13$ & 541.4648 & 31.65000 & 72.83550 & $2.59 \mathrm{E}+13$ & $8.88 \mathrm{E}+12$ & $8.84 \mathrm{E}+09$ \\
\hline Minimum & $1.62 \mathrm{E}+13$ & 50.16845 & 8.916667 & 5.382224 & $1.52 \mathrm{E}+10$ & $7.25 \mathrm{E}+09$ & $1.89 \mathrm{E}+08$ \\
\hline Std. Dev. & $1.81 \mathrm{E}+13$ & 122.7077 & 4.907397 & 17.45052 & $8.21 \mathrm{E}+12$ & $2.69 \mathrm{E}+12$ & $2.60 \mathrm{E}+09$ \\
\hline Skewness & 0.832401 & 1.789268 & 0.192748 & 1.699770 & 1.358928 & 0.949421 & 1.033243 \\
\hline Kurtosis & 2.206177 & 5.314061 & 3.595521 & 4.677334 & 3.368510 & 2.628913 & 2.811689 \\
\hline Jarque-Bera & 5.244317 & 27.99790 & 0.775847 & 22.15424 & 11.59725 & 5.770927 & 6.638147 \\
\hline Probability & 0.072646 & 0.000001 & 0.678464 & 0.000015 & 0.003032 & 0.055829 & 0.036186 \\
\hline Observations & 37 & 37 & 37 & 37 & 37 & 37 & 37 \\
\hline $\ln \mathrm{RGDP}_{\mathrm{t}}$ & 1 & & & & & & \\
\hline $\operatorname{lnREEX} X_{t}$ & -0.34306 & 1 & & & & & \\
\hline $\operatorname{lnINR} \mathrm{t}_{\mathrm{t}}$ & 0.20914 & -0.81230 & 1 & & & & \\
\hline $\operatorname{lnLINF}_{\mathrm{t}}$ & -0.29259 & -0.15062 & 0.30075 & 1 & & & \\
\hline $\ln \mathrm{MS}_{\mathrm{t}}$ & 0.96152 & -0.40889 & 0.35738 & -0.26621 & 1 & & \\
\hline $\operatorname{lnOREV}_{\mathrm{t}}$ & 0.88520 & -0.51762 & 0.48525 & -0.23977 & 0.96523 & 1 & \\
\hline $\operatorname{lnFDI} I_{t}$ & 0.87893 & -0.45051 & 0.36521 & -0.14019 & 0.90719 & 0.90775 & 1 \\
\hline
\end{tabular}

Source: Authors Computation using Eviews 9.

\subsection{Unit Root Tests Results}

Even though the ARDL framework does not require pre-testing the variables for stationarity, but the tests could justify the use of the ARDL bound testing approach to co-integration or otherwise. Consequently, we used the Augmented Dickey-Fuller (ADF) and Philip-Peron (PP) tests to ascertain the time series properties of the variables. The results from the ADF unit root test is presented in Table 1 indicated that the variables $\ln \operatorname{liDP}_{t}, \ln I N R_{t}$, $\operatorname{lnREEX}_{t}, \operatorname{lnOREV}_{t}$ and $\operatorname{lnMS} S_{t}$ are I (1) series and $\operatorname{lnFDI} t$ and $\operatorname{lnINF}_{t}$ are I (0) series. The Philip-Peron test also report five of the variables as I (1) series and two others as I (0), these findings corroborate the results of Inam and

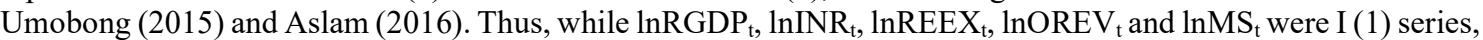
two other variables were I (0) series, leading support to the use of bound testing approach to co-integration. Table 2: Unit Root Test Results

\begin{tabular}{|c|c|c|c|c|c|c|c|c|c|}
\hline \multirow{2}{*}{\multicolumn{3}{|c|}{ Level }} & \multicolumn{4}{|c|}{$\begin{array}{c}\text { First } \\
\text { Difference }\end{array}$} & \multirow[b]{2}{*}{ PP } & & \multirow[b]{3}{*}{$\mathrm{I}(\mathrm{d})$} \\
\hline & & & \multicolumn{2}{|c|}{ PP } & \multicolumn{2}{|c|}{$\mathrm{ADF}$} & & & \\
\hline Variables & Constant & $\begin{array}{l}\text { Constant } \\
\& \text { Trend }\end{array}$ & Constant & $\begin{array}{l}\text { Constant } \\
\& \text { Trend }\end{array}$ & Constant & $\begin{array}{l}\text { Constant } \\
\& \text { Trend }\end{array}$ & Constant & $\begin{array}{l}\text { Constant } \\
\& \text { Trend }\end{array}$ & \\
\hline $\operatorname{lnRGDP}_{t}$ & $\begin{array}{c}0.142 \\
(0.96)\end{array}$ & $\begin{array}{l}-1.488 \\
(0.81)\end{array}$ & $\begin{array}{l}0.953 \\
(0.10)\end{array}$ & $\begin{array}{c}-3.108 \\
(0.12)\end{array}$ & $\begin{array}{c}-3.750 \\
(0.00)^{* * *}\end{array}$ & $\begin{array}{l}-3.672 \\
(0.04)^{* *}\end{array}$ & $\begin{array}{l}-3.750 \\
(0.00) \\
* * *\end{array}$ & $\begin{array}{l}-3.672 \\
(0.04)^{* *}\end{array}$ & $\mathrm{I}(1)$ \\
\hline $\operatorname{lnINR}_{t}$ & $\begin{array}{l}-2.402 \\
(0.15)\end{array}$ & $\begin{array}{l}-2.023 \\
(0.57)\end{array}$ & $\begin{array}{l}-2.412 \\
(0.15)\end{array}$ & $\begin{array}{r}-2.024 \\
(0.57)\end{array}$ & $\begin{array}{l}-5.868 \\
(0.00)^{* * *}\end{array}$ & $\begin{array}{l}-6.046 \\
(0.00)^{* * *}\end{array}$ & $\begin{array}{l}-5.873 \\
(0.00)^{* * *}\end{array}$ & $\begin{array}{l}-6.048 \\
(0.00)^{* * * *}\end{array}$ & $\mathrm{I}(1)$ \\
\hline $\ln \mathrm{REEX}_{\mathrm{t}}$ & $\begin{array}{l}-2.128 \\
(0.24)\end{array}$ & $\begin{array}{l}-1.998 \\
(0.58)\end{array}$ & $\begin{array}{l}-2.313 \\
(0.17)\end{array}$ & $\begin{array}{l}-2.264 \\
(0.44)\end{array}$ & $\begin{array}{l}-4.521 \\
(0.00)^{* * *}\end{array}$ & $\begin{array}{l}-4.509 \\
(0.00)^{* * *}\end{array}$ & $\begin{array}{l}-4.426 \\
(0.00)^{* * *}\end{array}$ & $\begin{array}{l}-4.332 \\
(0.00)^{* * *}\end{array}$ & $\mathrm{I}(1)$ \\
\hline $\operatorname{lnFDI} I_{t}$ & $\begin{array}{l}-1.620 \\
(0.46)\end{array}$ & $\begin{array}{l}-5.474 \\
(0.00)^{* * *}\end{array}$ & $\begin{array}{r}-1.396 \\
(0.57)\end{array}$ & $\begin{array}{l}-3.773 \\
(0.03)^{* *}\end{array}$ & - & - & - & - & $\mathrm{I}(0)$ \\
\hline $\operatorname{lnOREV} V_{t}$ & $\begin{array}{r}-1.419 \\
(0.56)\end{array}$ & $\begin{array}{r}-0.680 \\
(0.97)\end{array}$ & $\begin{array}{l}-1.476 \\
(0.53)\end{array}$ & $\begin{array}{r}-0.620 \\
(0.97)\end{array}$ & $\begin{array}{l}-5.986 \\
(0.00)^{* * *}\end{array}$ & $\begin{array}{l}-5.222 \\
(0.00)^{* * *}\end{array}$ & $\begin{array}{l}-5.986 \\
(0.00)^{* * *}\end{array}$ & $\begin{array}{l}-6.599 \\
(0.00)^{* * *}\end{array}$ & $\mathrm{I}(1)$ \\
\hline $\operatorname{lnMS} \mathrm{S}_{\mathrm{t}}$ & $\begin{array}{l}-0.926 \\
(0.77)\end{array}$ & $\begin{array}{r}-2.194 \\
(0.48)\end{array}$ & $\begin{array}{r}-0.488 \\
(0.88)\end{array}$ & $\begin{array}{r}-1.770 \\
(0.70)\end{array}$ & $\begin{array}{l}-3.048 \\
(0.04)^{* *}\end{array}$ & $\begin{array}{l}-3.400 \\
(0.07)^{*}\end{array}$ & $\begin{array}{c}-2.800 \\
(0.07)^{*}\end{array}$ & $\begin{array}{l}-2.569 \\
(0.30)\end{array}$ & $\mathrm{I}(1)$ \\
\hline $\operatorname{lnINF}_{t}$ & $\begin{array}{l}-3.299 \\
(0.02)^{* *}\end{array}$ & $\begin{array}{l}-4.265 \\
(0.00)^{* * *}\end{array}$ & $\begin{array}{l}-3.179 \\
(0.03)^{* *}\end{array}$ & $\begin{array}{l}-3.086 \\
(0.12)\end{array}$ & - & - & - & - & $\mathrm{I}(0)$ \\
\hline
\end{tabular}

Source: Authors Computation using Eviews 9. Note: ${ }^{* * *,{ }^{* *} \& *}$ represents statistically significant at $1 \%, 5 \%$ \& $10 \%$ levels and Numbers in parentheses are the p-values. 


\subsection{Optimum Lag Selection Criteria}

From the results of the unrestricted vector auto regression, using sequential modified LR test statistic (each test at 5\% level), Schwarz criterion (SC) and Hannan-Quinn criteria (HQ) information criteria revealed that lag 1 should be selected. Whereas Final prediction error (FPE) and Akaike info criterion (AIC) shows that lags 2 should be selected. Therefore, in line with the Schwarz criterion (SC) information criteria, lag 1 is the optimal lag length for this study. Hence, we lagged the variables 1 times.

Table 3. Optimum Lag Selection Criteria result

\begin{tabular}{ccccccc}
\hline \hline Lag & LogL & LR & FPE & AIC & SC & HQ \\
\hline \hline 0 & -123.4516 & NA & $2.53 \mathrm{e}-07$ & 7.511522 & 7.867030 & 7.634244 \\
1 & 130.4365 & $377.2052^{*}$ & $5.38 \mathrm{e}-12$ & -3.339228 & $-0.139655^{*}$ & $-2.234736^{*}$ \\
2 & 209.9846 & 81.82088 & $4.12 \mathrm{e}-12^{*}$ & $-4.227690^{*}$ & 1.815949 & -2.141427 \\
\hline \hline
\end{tabular}

Source: Authors Computation using Eviews 9. Note: ${ }^{*}$ represents statistically significant at 5\%.

\subsection{Bound Test for Co-integration}

We examined the long-run relationship amongs the variables in the model by conducting the ARDL bounds test proposed by Pesaran et al. (2001). The result of the bound test is presented in Table 4. The results indicated no co-integration, as it was inconclusive at the 5 per cent level, with the calculated F-statistics falling between the lower and upper critical values. Consequently, trade openness (OPN) was dropped from the model, the results from the new model showed that the null hypothesis of no co-integration amongst included variables is rejected at the 5 per cent level. The F- statistic was 3.73, which was higher than the upper bound of the critical values at the 5 per cent level (3.61) and implies the presence of a long-run relationship amongst the variables and this is in line with the work of researchers such as Oiro (2015), Razzaque et al. (2017) and Koirala (2018). Maximum lag of 2 was chosen in the ARDL Co-integration test since the study utilized yearly data series. The optimal lag length was chosen in line with Schwarz criterion (SC) and the selected ARDL representation for the model was ARDL $(1,1,0,1,0,0,1)$.

Table 4: ARDL Bound Test for Co-integration

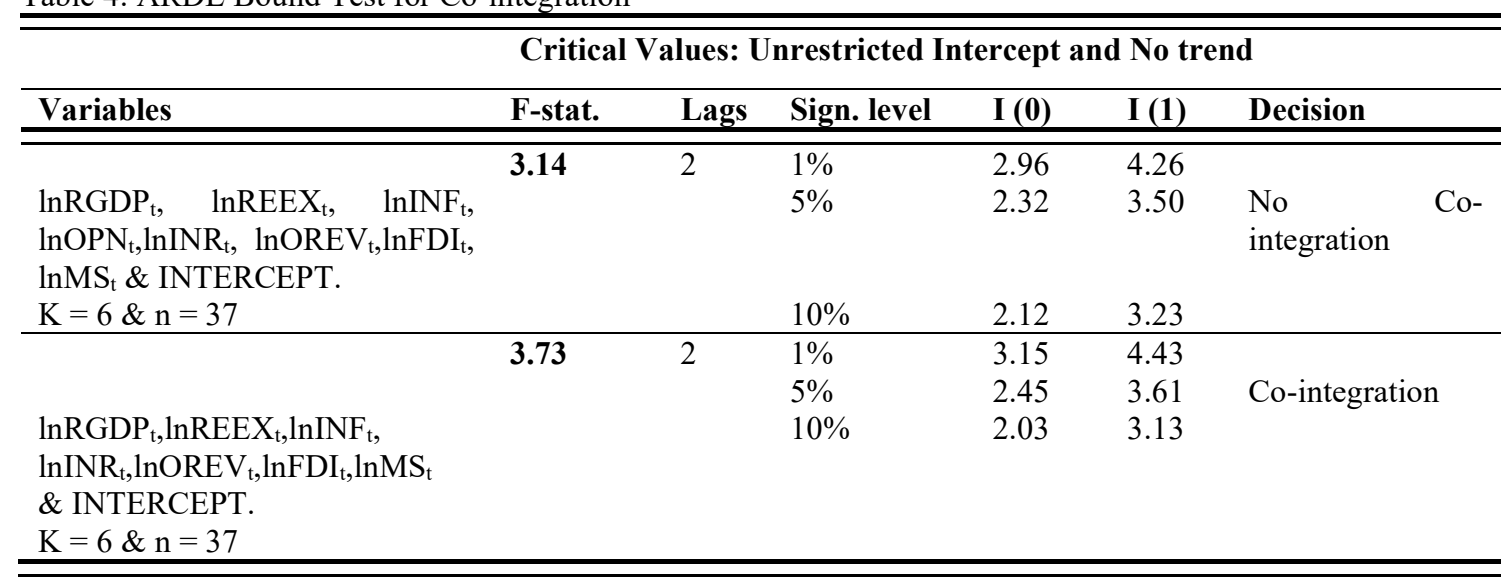

Source: Authors Computation using Eviews 9.

\subsubsection{Johansen Juselius Test for Co-integration}

The Johansen juselius test for co-integration using model with Trace statistics and model with Max-Egen value confirm the findings of the ARDL Bound test for co-integration for the existence of long-run relationships among the dependent and independent variables. Meaning that these variables jointly move together in the long run. This result corroborates the work of researchers such as Eze and Okpala (2014), Oiro (2015), Koirala (2018) and Ufoeze et al. (2018), etc. 
Table 4b: Johansen Juselius Test for Co-Integration Results

\begin{tabular}{cccc}
\hline $\begin{array}{c}\text { Hypothesized } \\
\text { No. of CE(s) }\end{array}$ & Eigenvalue & $\begin{array}{c}\text { Trace } \\
\text { Statistic }\end{array}$ & $\begin{array}{c}\text { Max-Eigen } \\
\text { Statistic }\end{array}$ \\
\hline $\mathrm{C}=0$ & 0.765635 & $172.2224(0.000)^{* * *}$ & $50.7807(0.0153)^{* *}$ \\
$\mathrm{C} \leq 1$ & 0.633821 & $121.4417(0.000)^{* * *}$ & $35.1622(0.1615)$ \\
$\mathrm{C} \leq 2$ & 0.614204 & $86.2796(0.001)^{* * *}$ & $33.3356(0.0579)$ \\
$\mathrm{C} \leq 3$ & 0.466679 & $52.9439(0.015)^{* *}$ & $22.0021(0.2202)$ \\
$\mathrm{C} \leq 4$ & 0.378940 & $30.9418(0.037)^{* *}$ & $16.6714(0.1881)$ \\
$\mathrm{C} \leq 5$ & 0.213500 & $14.2704(0.076)$ & $8.4057(0.3390)$ \\
$\mathrm{C} \leq 6$ & 0.154276 & $5.8647(0.015)^{* *}$ & $5.8647(0.0154)^{* *}$ \\
\hline \hline
\end{tabular}

Source: Authors Computation using Eviews 9. Note: ${ }^{* * *} \&{ }^{* *}$ represents statistically significant at $1 \%$ \& $5 \%$ levels and Numbers in parentheses are the p-values.

\subsection{ARDL Long Run and Short Run Results}

The result of both the long-run and short-run are presented in table 5. Results from the long run model showed real effective exchange rate and inflation rate are negatively and significantly related with economic growth in Nigeria. Meaning that a percentage change in foreign exchange and the rate of inflation will cause a decrease in economic growth by approximately $0.37 \%$ and $0.18 \%$ respectively and this result corroborate the findings of Obi et al. (2016), Ufoeze et al. (2018) and Barguellil et al. (2018). Whereas money supply is positive and significant in explaining economic growth in Nigeria, i.e. a percentage change in money supply will cause GDP to increase by $0.17 \%$, this is in line with work of Ufoeze et al (2018). All the remaining variables are insignificance in explaining economic growth activities in the long run. While in the short run real effective exchange rate is also negative but insignificant in explaining economic growth in Nigeria. Like money supply is also negative but having significant impact in explaining economic growth in the short run. Meaning that a percentage change in money supply will decrease the rate of economic growth by approximately $0.11 \%$ in the short run.

ECM value of -0.2074 with probability value of 0.014 indicate the speed of adjustment between the variable toward long equilibrium and also its probability is at 5 percent level of significant meaning the whole system can get back to equilibrium at a slow speed of 21 per cent in the current period. The R-squared value of 0.99 indicates that 99 per cent variation in the dependent variable (i.e. Real Gross Domestic Product) can be jointly explained by the independent variables (i.e. Real Effective Exchange Rate, Money Supply, Interest Rate, Foreign Direct Investment, Oil Revenue and Inflation Rate) and only 1 per cent variation is capture by the stochastic error term. The test of the overall significant of the model is shown by the F-statistic value of 2156.240 and its probability value of 0.000 . meaning that the overall ARDL Model is statistically significant at 1 per cent which is more stringent. The Durbin-Watson statistic value of 1.729 is higher than 1.5 which entails the absence of first order serial autocorrelation problem. 
Table 6: Long Run and Short Run Coefficients

\begin{tabular}{|c|c|c|c|}
\hline \multicolumn{4}{|c|}{ Estimated Long-run Coefficients- Dependent Variable: InRGDP } \\
\hline Variable & Coefficient & t-Statistic & Prob. \\
\hline $\mathrm{C}$ & $28.8872^{* * *}$ & 17.9655 & 0.000 \\
\hline $\operatorname{lnREEX_{\mathrm {t}}}$ & $-0.3688^{* * *}$ & -2.9234 & 0.007 \\
\hline $\operatorname{lnINF} F_{t}$ & $-0.1752^{* *}$ & -2.1119 & 0.044 \\
\hline $\operatorname{lnINR} R_{t}$ & -0.2865 & -1.2711 & 0.215 \\
\hline $\operatorname{lnOREV} V_{t}$ & -0.0141 & -0.1732 & 0.864 \\
\hline $\operatorname{lnFDI} I_{t}$ & 0.0546 & 0.7529 & 0.459 \\
\hline $\ln \mathrm{MS}_{\mathrm{t}}$ & $0.1722^{* *}$ & 2.4388 & 0.022 \\
\hline \multicolumn{4}{|c|}{ Error Correction Representation of the ARDL Model-Dependent Variable: $\triangle \ln R G D P_{t}$} \\
\hline Variable & Coefficient & t-Statistic & Prob. \\
\hline$\Delta \operatorname{lnREEX} \mathrm{t}_{\mathrm{t}}$ & -0.0053 & -0.2279 & 0.822 \\
\hline$\Delta \operatorname{lnINF} F_{t}$ & $-0.0363^{* * *}$ & -2.7727 & 0.010 \\
\hline$\Delta \operatorname{lnINR} R_{t}$ & 0.0374 & 0.5970 & 0.560 \\
\hline$\Delta \operatorname{lnOREV} \mathrm{t}_{\mathrm{t}}$ & -0.0029 & -0.1664 & 0.869 \\
\hline$\Delta \operatorname{lnFDI} I_{t}$ & 0.0113 & 0.7384 & 0.467 \\
\hline $\ln \mathrm{MS}_{\mathrm{t}}$ & $-0.1075^{*}$ & -1.7766 & 0.088 \\
\hline $\mathrm{EMC}_{\mathrm{t}-1}$ & $-0.2074^{* *}$ & -2.6353 & 0.014 \\
\hline $\mathrm{R}^{2}: 0.996, \mathrm{DW}-\mathrm{s}$ & $\mathrm{t}: 667.595^{* * *}$ & & \\
\hline
\end{tabular}

Source: Authors Computation using Eviews 9 . Note: ${ }^{* * *},{ }^{* *} \&{ }^{*}$ represents statistically significant at $1 \%$ \& 5\% levels and Numbers in parentheses are the p-values.

\subsection{ARDL Short Run Wald Test}

The result of the short run Wald test conducted is presented in table 7 . The result has indicated that all the coefficients of the independent variables combined together are statistically significance at 1 per cent which is more stringent. Meaning that these variables have significance impact in explaining economic growth in Nigeria for the period under study. It also Means that all the variables have long run relationship or moved together in the long run.

Table 7: ARDL Long Run Wald Test Results

\begin{tabular}{c|c|c|c}
\hline Null Hypothesis & F-statistics & Df & Result \\
\hline \hline All coefficients are zero & $39.0767^{* * *}(0.000)$ & $(6,25)$ & Reject the null \\
Constant is zero & $28.8872^{* * *}(0.000)$ & & Reject the null \\
\hline
\end{tabular}

Source: Authors' 2019 using Eviews 9; Note: ${ }^{* * *}$ represents statistically significant at 1\% level.

\subsection{Diagnostic Tests}

The estimation was done to give unbiased and consistent estimates even in the face of heteroscedasticity, while the result of the Breusch Pagan test reveals that the null hypothesis of no serial autocorrelation is not rejected at $5 \%$ level of significance. The Jarque-Bera test normality of the model also affirms that the model is well specified and in the right functional form, thus conforming that the model is a well-behaved model. The Ramsey RESET test shows that the null hypothesis of model misspecification cannot be reject at 5 per cent level. figure 1 and figure 2 presents the stability sketch of the estimated model, the CUSUM shows that the blue line is within the 5 per cent upper and lower ridges lines meaning that the model is dynamically stable. While using CUSUM of Squares there is a slight deviation from the 5 per cent upper and lower ridges lines which means that the model is not dynamically stable. 
Table 8. The Results of ARDL Diagnostic Tests.

\begin{tabular}{cc}
\hline Test & Serial correlation \\
\hline F-stat & $0.2838(0.756)$ \\
Observed $\mathrm{R}^{2}$ & $0.8671(0.648)$ \\
\hline Test & Heteroscedasticity: ARCH \\
\hline F-stat & $0.4776(0.494)$ \\
Observed $\mathrm{R}^{2}$ & $0.4993(0.480)$ \\
\hline Test & Normality test \\
\hline Jarque-Bera & $0.1646(0.921)$ \\
\hline Test & Ramsey RESET \\
\hline F-stat & $5.9416(0.023)$ \\
\hline
\end{tabular}

Source: Authors' 2019 using Eviews 9. Note; Numbers in brackets are the p-values.
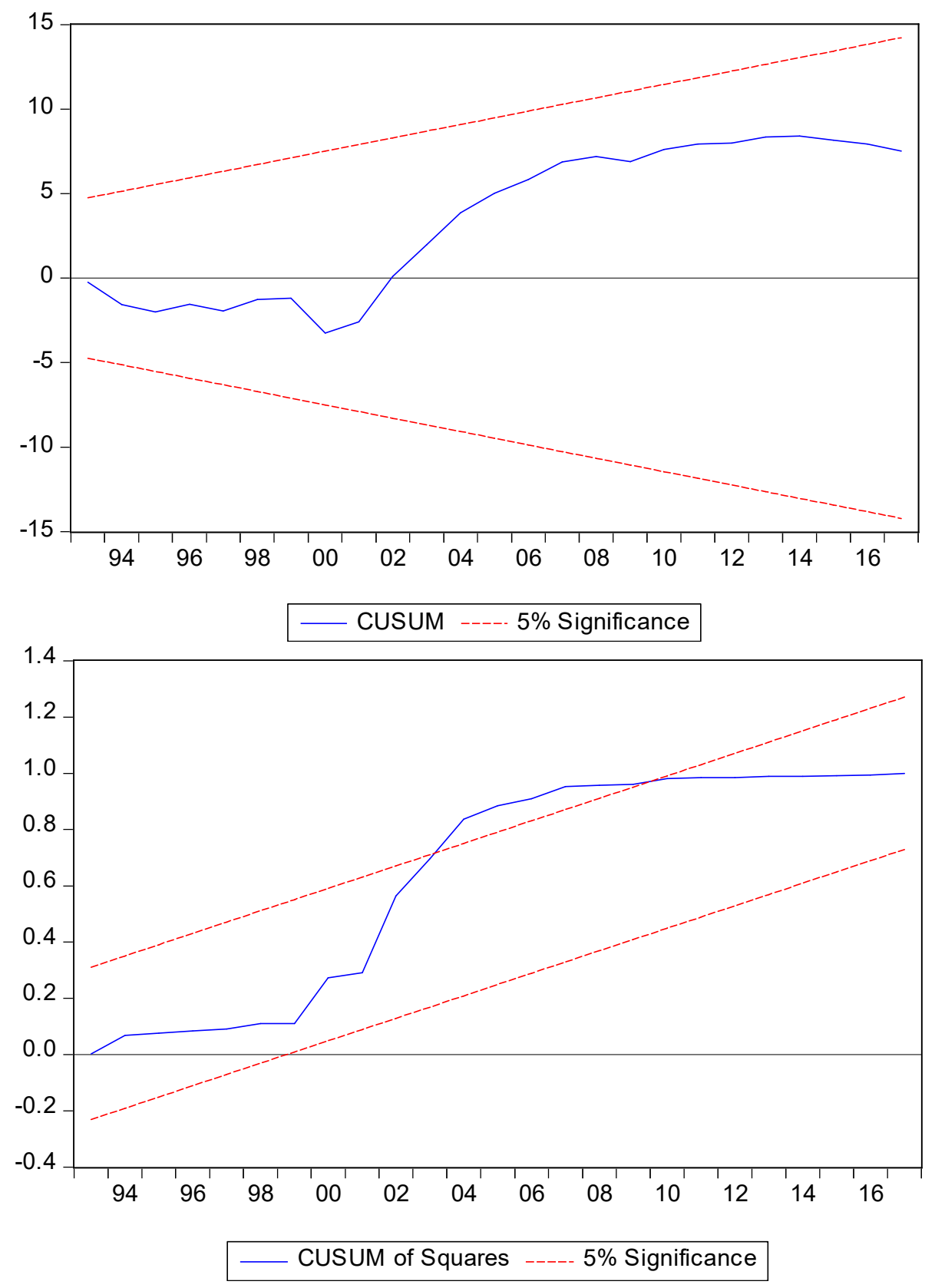


\subsection{SUMMARY AND CONCLUSION}

Having estimated the model and conducted post-estimation reliability tests which the result reveal that the estimated model is highly dynamically stable and free from serial correlation as well as free from heteroscedasticity problem and also having the errors normally distributed. Therefore, the model fits with the analysis. The results of the estimated model reveal that real effective exchange rate have negative impact on economic growth in Nigeria from 1981 to 2017 both in the short-run and long-run with significant influence in the long- run. Also, in the same short-run, the lag value of real effective exchange rate is insignificant in explaining the changes in the current rate of economic growth. in the same period, the lag value of money supply is negative and significant in explaining GDP. But in the long run it is positive and significant in explaining economic growth in Nigeria. The rate of inflation both the short run and long run is negatively and significant in explaining GDP. with significant positive effect on inflation and the same thing applies to the long-run money supply. ECM value of -0.20774 indicate that the speed of adjustment between the variable toward long run equilibrium is around 21 per cent and also its probability is at 5 percent level of significant meaning that the whole system can get back to equilibrium at a slow speed of 21 per cent in the current period. The Johansen Juselius test for co-integration serve as the robust check which corroborate the results of ARDL co-integration test in the model. Therefore, the research concludes that the real effective exchange rate effect on economic growth during the short-run and long-run periods under study in Nigeria is negative.

\section{References}

Adeniram, J.O., Yusuf, S.A. and Adeleyi, O.A. (2014) The Impact of Exchange Rate Fluctuation on Nigerian Economic Growth: An Empirical Investigation, International Journal of Academic Research in Business and Social Sciences, 4(8): 224-233. Retrieved 14 ${ }^{\text {th }}$ June 2019 from www.hrmars.com

Barguelil,A., Ben-Salha, O., and Zmami, M. (2018) Exchange Rate Volatility and Economic Growth, Journal of Economic Integration, 33(2):1303-1336, Retrieved from 14 ${ }^{\text {th }}$ June 2019 from http://dx.doi.org

Barry,E. (2008) the Real Exchange Rate and Economic Growth, International Bank for Reconstruction and Development working paper No.4,PP: 1-35, Retrieved from www.iiste.org

Bobai, F.D., Ubangida, S. and Umar, Y.S. (2013) An Assessment of Exchange Rate Volatility and Inflation in Nigeria, Journal of Emerging Issues in Economics Finance and Banking (JEIEFB), 11(4): 321-340. Retrieved $14^{\text {th }}$ June 2019 from www.globalbizresearch.com

Central Bank of Nigeria Statistical Bulletin 2018 at www.cbn.gov.ng

Eze,T.C. and Okpala,C.S. (2014) Quantitative Analysis of the Exchange Rate Policies on Nigeria's Economic Growth: A Test of stability of parameter Estimate, Intl Journal of Humanities \& Social sciences , 4(7): 265 272. Retrieved $14^{\text {th }}$ June 2009 from www.ijhssnet.com

Inam,U. and Umobong, E.C. (2015).An Empirical Analysis of the Relationship between Exchange Rate movements and Economic Growth in Nigeria, European Journal of Business and management,7(30): 191199. Retrieved $14^{\text {th }}$ June 2019 from www.iiste.org

Jacob, B. (2016) Impact Of Exchange Rate Regimes On Economic Growth, Undergraduate Economic Review 12(1): 1-22 Retrieved $14^{\text {th }}$ June 2019 from http://digitalcommons'iwu'edu/uer/voll2/isss1/11.

Jhingam, L.M. (2013) Advanced Economic Theory, vvida Publishers (P), New Delhi, India.

Koirala, S. (2018) An Analysis of the Impact of Real Effective Exchange Rate on Economic Growth of Nepal, Parvaha journal of economic management: 206-216

Mordi, C.N.O. (2006). Challenges in Exchange Rate and Volatility in Economics Management in Nig, CBN Bulletin 30(3): July-Sept 2016.

Muhammed Aslam, A.L. (2016) Impact of Exchange Rate on Economic Growth in Srilanka World Scientific News 54: 252-266 Retrieved $14^{\text {th }}$ June 2019 from www.worldscientificnews.com

Obi, K.O., Oniore, J.O. and Nnad, K.U. (2016) The Impact of Exchange Rate Regimes on Economic Growth in Nigeria, Journal of Economic and Sustainable Development, 7(12): 115-127, Retrieved 14 ${ }^{\text {th }}$ June 2019 from www.iiste.org

Oladapo,F. and Oloyede, J.A, (2014) . Nigerian Economic Growth, European Journal of British And Innovation Research, 2(2): 19-31. Retrieved $14^{\text {th }}$ June 2019, from www.ea-journals.org.

Perpetua, U.I. (2014) Impact of Exchange Rate Variation and Inflation on Economic Growth of Nigeria: An Empirical Research Approach Journal of Finance and Accounting, 5(22): 166-176. Retrieved June $14^{\text {th }} 2019$ from www.iiste.org

Razzaque,M.A., Bidisha, H.A., Khondker, B.H. (2017) Exchange Rate and Economic Growth: An Empirical Assessment for Bangladesh, Journal of South Asian Development, 12(1): 42-46, Retrieved June 14 ${ }^{\text {th }}, 2019$ from sagepub:in/home.nav or http://sad.sagepub.com

Ufoeze, L.O., Okuma, C.N. Nwakoby. C. and Alayekwu, U.B. (2018). Effect of Foreign Exchange Rate Fluctuation in Nigerian Economy, Economic series issue 1: 105-122, Annals of Spiru Haret University

World Bank Development Indicators at www.worldbank.org/indicators 